\title{
JSE EFFICIENCY AND SHARE PRICE REACTION TO FORCED FINANCIAL RESTATEMENTS
}

\author{
Shaun Watson" \\ University of the Free State \\ watsonsa@ufs.ac.za
}

\author{
Jacobus Rossouw + \\ University of the Free State \\ Rossouw」@ufs.ac.za
}

February 2012

\begin{abstract}
This study uses an event study methodology to empirically examine share price reaction to financial restatement announcements resulting from investigations or recommendations by the GAAP Monitoring Panel and tests, in semi-strong form, the efficiency of the Johannesburg Securities Exchange (JSE). The results indicate that companies making such financial restatement announcements experience significant negative standardised abnormal returns ten days before and five days subsequent to the announcement. As evidenced by the significant negative standardised abnormal returns, it would appear that the announcements convey new information to the market. Although the lack of consecutive negative standardised abnormal returns around the announcement date would suggest that the JSE is efficient in semi-strong form, the five-day time lag between the announcement date and the significant negative standardised abnormal return supports the rejection of semi-strong form efficiency of the JSE.
\end{abstract}

Keywords

JSE efficiency, restatement of financial statements, event study, abnormal returns, GAAP Monitoring Panel

\#Mr Shaun Watson is senior lecturer at the Centre of Accounting, University of the Free State, Bloemfontein, South Africa.

+Prof Cobus Rossouw is associate professor at the Centre of Accounting, University of the Free State, Bloemfontein, South Africa. 


\section{INTRODUCTION AND BACKGROUND}

The efficient market hypothesis (EMH) posits that share prices in an efficient market will at any time fully reflect all available information. While unexpected events may result in abnormal returns in the market, these abnormal returns should not last long enough to enable diligent investors to consistently earn abnormal returns (Fama, Fisher, Jensen \& Roll, 1969). The unexpected events of the highly publicised corporate failures (e.g. Enron, Adelphia Bristol-Myers Squibb, Cendant, Global Crossing, Qwest, Tyco, WorldCom, HealthSouth, Sunbeam, Waste Management, LeisureNet (South Africa), ComROAD AG (Germany), 1200110Lernout \& Hauspie Speech Products (Belgium), Parmalat (Italy), Royal Ahold (Netherlands)) resulted in capital markets around the world experiencing a loss of investor confidence (Rezaee, 2004). For many of these companies the financial restatement had a devastating effect, with equity values plummeting and credit ratings often reduced to junk status (Agrawal \& Chadha, 2005).

As equity values and credit ratings plummeted, inefficient corporate governance and unreliable financial reporting were widely cited as reasons for the financial restatements and ensuing corporate scandals (Browning \& Weil, 2002). The alarming increase in the frequency of earnings restatements that preceded these corporate failures further fuelled revelations about the unreliability of reported earnings (Agrawal \& Chadha, 2005).

The South African response to the loss of investor confidence was a joint initiative between the South African Institute of Chartered Accountants (SAICA) and the JSE Limited that resulted in the formation of the GAAP Monitoring Panel (GMP) on 4 September 2002. The GMP serves as an oversight body to 'investigate complaints and advise the Johannesburg Securities Exchange (JSE) in relation to compliance by issuers with International Financial Reporting Standards (IFRSs), the JSE's required accounting practices (in terms of the Listings Requirements) and the accounting practices required by the Act' (JSE Limited, 2010c:175). After considering the advice of the GMP, the JSE may instruct companies to publish or re-issue any information the JSE deems appropriate and make a public announcement to this effect through the Securities Exchange News Service (SENS) (JSE Limited, 2010c:175).

The primary research objective of this study is to test, in semi-strong form, the efficiency of the JSE in reacting to the SENS announcements of financial restatement resulting from investigations by or work of the GMP. The secondary objective is to examine share price reaction to SENS announcements of financial restatement resulting from investigations by or work of the GMP.

On 16 February 2011 the JSE announced that it intended to enhance compliance with IFRS through the implementation of a new proactive financial statement review process (JSE Limited, 2011). Given that the new proactive review process will result in the financial statements of listed companies being reviewed at least once every five years, the study makes a contribution by indicating to the JSE and regulators the market's reaction to financial restatements resulting from the work of an oversight body such as the GMP. A study of the impact that financial restatement announcements have on share prices of JSE listed companies should further be of interest to management, investors and other interested parties.

A further motivation for the study comes from a review of the literature testing the efficiency of the JSE. The results of studies (Atkins, 1995; Glass \& Smit, 1995; Kana, 1986; Knight \& AffleckGraves, 1983; Okeahalam \& Jefferis, 1999) testing the efficiency of the JSE, in semi-strong form, may at best be described as contradictory. By examining the length of time it takes the JSE to 
react to financial restatements announcements, the study makes a contribution by testing the semi-strong form of the Efficient Market Hypothesis and thereby contributes to the literature.

The remainder of the article is as follows:

- Section 2 consists of the literature review.

- Section 3 addresses the event study methodology (the research methodology) applied in the study.

- Section 4 provides a descriptive and illustrative analysis of the data obtained, the statistical techniques used and the results yielded.

- Section 5 provides the conclusions of the study and

- Section 6 addresses the limitations and recommendations for future research.

\title{
2. LITERATURE REVIEW
}

In providing an overview of accounting standards and JSE listing requirements, the literature review highlights some of the technical aspects and requirements relating to financial restatements. This is followed by a review of the restatement literature as well as research on market efficiency and the efficient market hypothesis (EMH). The literature review concludes by highlighting some of the achievements of the JSE and various aspects that may influence the efficiency of the JSE. Given that the South African literature on financial restatement is limited, the US literature is used predominantly to illustrate the impact of financial restatement on share prices.

\subsection{International accounting standards and JSE listing requirements addressing financial restatement}

Although South African legislation provides no legal backing for accounting standards, the JSE listing requirements do require listed companies to comply with IFRSs. Paragraph 41 of International Accounting Standard 8 - Accounting Policies, Changes in Accounting Estimates and Errors (IAS 8) states that,

\begin{abstract}
Errors can arise in respect of the recognition, measurement, presentation or disclosure of elements of financial statements. Financial statements do not comply with IFRSs if they contain either material errors or immaterial errors made intentionally to achieve a particular presentation of an entity's financial position, financial performance or cash flows. Potential current period errors discovered in that period are corrected before the financial statements are authorised for issue. However, material errors are sometimes not discovered until a subsequent period, and these prior period errors are corrected in the comparative information presented in the financial statements for that subsequent period.
\end{abstract}

(International Accounting Standards Board, 2010: par.41). Paragraph 42 of IAS 8 further requires that '.. an entity shall correct material prior period errors retrospectively in the first set of financial statements authorised for issue after their discovery by: (a) restating the comparative amounts for the prior period(s) presented in which the error occurred; or (b) if the error occurred before the earliest prior period presented, restating the opening balances of assets, liabilities and equity for the earliest prior period presented' (International Accounting Standards Board, 2010:par.42). 
In addition to the requirements discussed above, numerous provisions of the JSE listing requirements require companies to correct any incomplete or misleading information. In terms of paragraph 8.65 of the listing requirements, 'the JSE will be able, in its sole discretion to censure such issuer in accordance with the provisions contained in Section 1 of the Listings Requirements and instruct such issuer to publish or re-issue any information the JSE deems appropriate' (JSE Limited, 2010c:8 - 25). The reporting entity accordingly has an obligation to correct prior period errors and provide the necessary disclosure about such restatements.

Prior studies on financial restatements have researched aspects including but not limited to the examination of determinants of market reaction to restatement announcements (Palmrose, Richardson \& Scholz, 2004), the contagion effects of accounting restatements (Gleason, Jenkins \& Johnson, 2008), the role of board independence in voluntary vs. forced restatements (Marciukaityte, Szewczyk \& Varma, 2009), the long-term reactions to earnings restatements (Xu, Jin \& Li, 2009), the role that industry expertise plays in reducing restatements (Chin \& Chi, 2009), the reputational penalties to managers of companies announcing earnings restatements (Desai, Hogan \& Wilkins, 2006), the avoidance of reputational damage in financial restatements (Gertsen, van Riel \& Berens, 2006) and the relationship between restatements and litigation (Palmrose \& Scholz, 2004).

The correction of prior period errors effectively equates to an admission that previously authorised and audited financial reports contain misrepresentations. The correction of financial results, therefore, poses a risk to the entity in that investors may alter their perceptions about the companies' past and future performance (Palmrose \& Scholz, 2004). Studies examining the relation between restatement announcements and average share price reactions to such restatements find that share prices of restating companies are on average negatively affected. The percentage by which share prices change vary between $-6 \%$ (Dechow, Sloan \& Sweeney, 1996) and $-9 \%$ (Palmrose et al., 2004).

Palmrose et al. (2004) further found that for $29 \%$ of the restatement announcements included in their sample the share price was not adversely affected by the restatement. Palmrose et al. (2004) provide a plausible explanation that the restatements may involve minor corrections and, therefore, have minimal impact on investor perceptions or that information already disclosed through the media lessens the impact of the restatement or that investors already anticipate the restatements possibly due to industry specific or accounting issues.

\subsection{Capital market research}

With the objectives of the study being to test the semi-strong form of efficiency of the JSE and examine share price reaction to restatement announcements resulting from investigations by or work of the GMP, the literature review on capital market research focuses on market efficiency and the efficient market hypothesis (EMH).

\subsubsection{Market efficiency}

Fama (1970:1) defines an efficient market as a market in which security 'prices at any time fully reflect all available information'. As security prices determine the allocation of wealth among companies and individuals, determining the information efficiency of capital markets is of great interest to investors, managers, standard setters, and other market participants (Kothari, 2001). In an efficient market, security prices would represent the security's true intrinsic worth and although market prices may at times deviate from this true intrinsic worth, these deviations 
should not last for long enough to enable diligent investors to consistently earn abnormal returns (Mandal \& Rao, 2010).

Market efficiency has important consequences for accounting and the role of accounting within the capital market. If $E M H$ is held to be true, rewards gained through diligent analysis of the annual financial reports would be diminish, security prices would not be affected by changes in accounting policies, standards (e.g. accounting for share options and research and development expenditure) and the choices of disclosure (Kothari, 2001). Alternatively, if markets are inefficient, changes in accounting policies, standards and the choices of disclosure would have important consequences from an accounting and reporting company's perspective. EMH is crucial to capital market research where the primary objective has been to assess whether in addition to all other sources of public information, accounting data provides valuerelevant information to investors.

\subsubsection{Efficient market hypothesis}

The efficient market hypothesis (EMH) posits that investors are rational and that all publically available information and financial information contained in companies' financial statements and disclosures are processed efficiently into the share price in an unbiased manner and that relevant information is not ignored (Deegan, 2007).

Reviewing work on market efficiency, Fama (1970) specified three forms of the efficient market hypothesis: the weak form, semi-strong form and strong form. In the weak form, share prices do not immediately impound new information but reflect all historical market information that may affect share prices. This means that diligent analysis of all available market information cannot be used to earn abnormal trading profits.

In the semi-strong-form, the market is efficient if announcements and events such as earning announcements, dividend declarations, share splits, restatements, etc. are immediately and accurately impounded into the share price and investors are accordingly not able to earn an abnormal trading profit. The results of studies applying semi-strong tests of market efficiency of the JSE can at best be described as contradictory (Mabhunu, 2004).

Examining the share price reaction of 21 industrial companies that changed the inventory valuation method from FIFO to LIFO, Knight and Affleck-Graves (1983) concluded that the market was inefficient as it was, firstly, reacting to a change in accounting policy, which does not necessarily affect the firm's future prospects, and, secondly, the market was reacting slowly to the announcement. Examining the efficiency of the JSE with respect to takeovers, Kana (1986) found that the JSE appears efficient in the timing of the takeover but inefficient in the assimilation of the accuracy of the takeover information. Glass and Smit (1995) examined the impact of publicly available information on share prices and found that the JSE is not efficient in the semi-strong form. Atkins (1995) examined the effect of supply and demand on the pricing of shares and found support for the semi-strong form of market efficiency. Supporting this finding, Okeahalam and Jefferis (1999) found that the JSE conformed to the semi-strong form of EMH for the period September 1996 to September 1997. Emphasising the contradictory findings, Philpott and Firer (1995:39) state that: 'Since none of the research supporting the EMH proved that the JSE is efficient, but rather merely failed to detect inefficiencies, it may be concluded that the JSE is not efficient in the semi-strong form.'

Lastly, in the strong form, the market is said to be efficient where share prices reflect both private and public information and any new information dispersed in the market immediately 
with everyone having access to the same information at the same time. Hence investors, even those with access to private information about a company, should not be able to consistently earn abnormal returns.

In relation to the efficiency of the JSE, Thompson and Ward (1995) performed an extensive review of studies examining the efficiency of the JSE and concluded that, with different methodologies producing different results, no conclusive answer as to the efficiency of the JSE could be reached. Studies (Hellman, 2002; Jefferis \& Smith, 2004, 2005; Mabhunu, 2004; MacDonald, 1995; Magnusson \& Wydick, 2002; Okeahalam \& Jefferis, 1999; Robertson, Page \& Smit, 1999; Smith, 2008; Smith, Jefferis \& Ryoo, 2002) subsequent to the Thompson and Ward (1995) review have, however, found the JSE to be an efficient market.

It should be remembered that the efficiency of any security exchange is influenced by various factors such as the characteristics of the securities and their issuers, the characteristics of the market, the level of technology applied, the information dissemination, the size of the market, the regulation of the stock market, the costs of trading, etc. (Mandal \& Rao, 2010). Researching factors contributing to the efficiency of the JSE is beyond the scope of this study, and, therefore, an overview of the JSE and its achievements is provided as background information.

\subsection{Johannesburg Securities Exchange}

Since its modest beginnings in 1886, the JSE has evolved to one of the top 20 largest equity exchanges in the world, with a market capitalisation of R6,445 billion at the end of October 2010 (JSE Limited, 2010a). In addition to being ranked among the 20 largest equity exchanges in the world, the 2010 World Economic Forum (WEF) ranked South Africa first out of 139 countries for its regulation of securities exchanges (JSE Limited, 2010d).

As share prices incorporate both private and public information ( $(i$, Goldstein \& Wei, 2007) the need to keep the market informed with public information cannot be emphasised enough. In order to facilitate the real time, equal and wide dissemination of relevant company information to holders of securities and any other interested parties, the JSE established SENS (previously known as Stock Exchange News Service) during August 1997 (JSE Limited, 2010b). The JSE listing requirements facilitate the release of information, including price-sensitive information, via SENS. The JSE listings requirements define price-sensitive information as, 'unpublished information that, if it were made public, would be reasonably likely to have an effect on the price of a listed company's securities' (JSE Limited, 2010c:11). To promote the equal distribution of information and to ensure confidentiality prior to announcement, price-sensitive information may not be released to a third party, within JSE trading hours, until published through SENS or outside JSE trading hours, until such information has been authenticated and arrangements have been made for announcement through SENS prior to the next opening of JSE trading hours (JSE Limited, 2010c:3-5). Should it happen that confidential information is disclosed in an unplanned manner, section 3.8 of the listing requirements requires that immediate steps be taken for a SENS announcement containing such price-sensitive information to be made (JSE Limited, 2010c:3-6)

\section{RESEARCH METHODOLOGY}

The event study methodology introduced by Fama, Fisher, Jensen and Rol (1969) examines the impact of firm specific events on the share price of the company. The event study methodology 
subsequently became the standard method of testing the efficiency of the market and measuring security price reaction to some announcement and or event (Binder, 1998).

While various models have been used in event studies, the market model, a standard simple linear regression where the returns for each share are regressed against the returns on a broad index, is widely used in examining the impact of an event on share prices and/or market efficiency (Corhay \& Tourani-Rad, 1996). Supporting the use of the market model in event studies, Brown and Warner (1980) conclude that the market model is well specified under a variety of conditions.

Similar to the Bremer and Zhang (2007), this study uses a two-stage event test methodology that incorporates the market model, to examine the effect of the financial restatement announcements on the restating company's share price. The research design and methodology followed are discussed in more detail below.

\subsection{Sample selection}

The McGregor BFA database 'is the pre-eminent provider of stock market, fundamental research data and news to the financial sector and the corporate market at large' (McGregor BFA, 2010). In order to identify the sample of financial restating companies, the McGregor BFA database was used to search for SENS announcements containing variations of the phrases 'GAAP Monitoring Panel', 'GMP', 'restate' and 'restatement' for the period l September 2002 - 30 September 2010. In addition to using the McGregor BFA database to identify financial restating companies, the database was also used to obtain the all-share index and company-specific share prices for the period 1 September 2002 - 30 0ctober 2010. The end date 30 0ctober 2010 was specifically selected to ensure that restating companies have at least 20 days of share data subsequent to the SENS restatement announcement (day 0) available.

In selecting the SENS announcement date as the event date, it is acknowledged that news of financial restatement may leak before the official SENS announcement. Section 3.7 of the JSE listing requirements does, however, address this risk by requiring that when a confidentiality breach exists and the market is aware of such price-sensitive information the issuer should immediately make a SENS announcement containing details of such information. It is accordingly acknowledged that while the possibility of the information leakage may have an impact on the event date and results found, it can unfortunately not be controlled in this study. As the JSE makes use of SENS and InfoWiz to ensure the real-time distribution of current market information, it is considered appropriate to use the SENS announcement date as the event date.

In addressing the validity of the sample, an academic clerk, using the same search criteria as stated above, independently compiled a list of restating companies with the corresponding SENS announcement dates. The two lists of restating companies and SENS announcement dates were reconciled and differences resolved by re-checking the SENS announcements. Where more than one SENS announcement made reference to the restatement resulting from an investigation by or work of the GMP, the first SENS announcement date was used.

To focus on financial restatements resulting from investigations by or work of the GMP only SENS announcements that indicated the restatement result from recommendations by or work of the GMP were included in the sample. The sample was further limited to include only companies with at least 108 days of share data before and 20 days after the restatement announcement date (day 0 ) as well as having shares traded during the 15-day period both before and after the restatement date. 
Where a company has more than one financial restatement resulting from investigations by or work of the GMP and the estimation and/or event periods overlap, only the first restatement was included in the sample. This eliminates the effect of double counting the share returns used to predict the abnormal returns.

\subsection{Research design}

A two-stage event test, which scales abnormal returns with conditional variance and is estimated with a $\operatorname{GARCH}(1,1)$ component, and an event indicator were used to examine the effect of the financial restatement announcements on the restating company's share price. This test increases the ability to correctly identify abnormal returns during event periods and is particularly useful for investigating events that have higher levels of event-induced volatility, smaller sample sizes and effect sizes (Bremer \& Zhang, 2007).

Using return data to estimate the parameters of the market model for each share in the sample, eliminates movements in share prices attributable to market-wide economic or common factors leaving the portion of the return attributable to firm specific information (Binder, 1998). The regression model is estimated for each company separately and the residuals from the market model for the event month is used as an estimator of the abnormal return for the share during the event month. These residuals are then averaged across companies in the sample and tested for significance using a T-test. Where the financial restatement announcement has no effect, the abnormal return is expected to be zero. Any movements away from zero are, therefore, attributed to the restatement announcement.

The first stage of the methodology is to eliminate market-wide or common factors affecting share prices in order to determine the abnormal returns. Distinguishing between the estimation and event periods (refer to FIGURE 1), the current study excludes the daily return data during the event period in estimating the parameters of the market model for each share in the sample. Including the event period data in estimating the market model parameters may bias the coefficient estimates as the effects of the event are then included in the estimates (Ball \& Brown, 1968). The exclusion of the event period data in estimating the market model parameters has become the standard approach to address this issue (Binder, 1998).

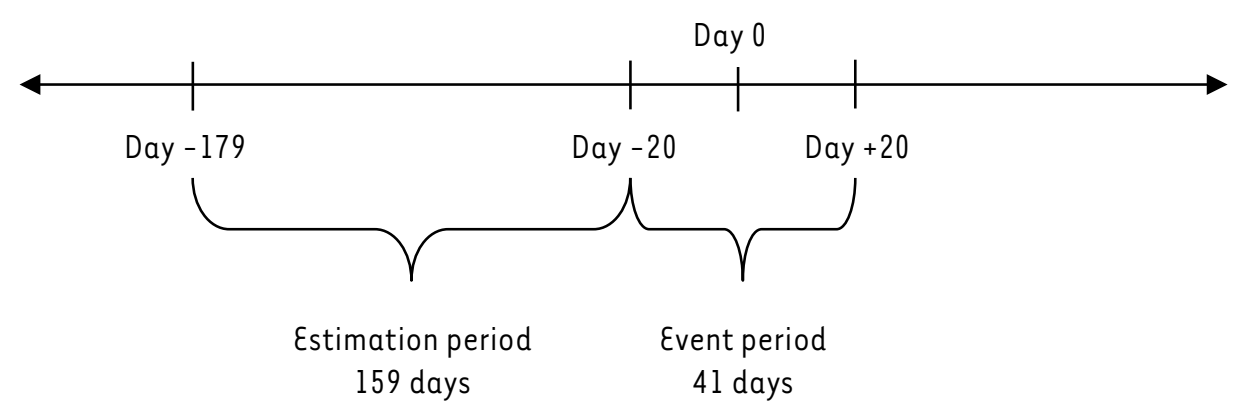

FIGURE 1: Timeline

\section{Source: Authors'own figure}

In order to account for time varying volatility change in the estimation period a GARCH (generalised autoregressive conditional heteroscedasticity) structure of order $(1,1)$ is added to the market model to produce the modified market model. 
After estimation of the modified market model (Formula 1 ) the abnormal returns ( $A R$ ) for each day in the event window (day -20 till day +20 ) are calculated as the difference between the expected share return $\left(\hat{R}_{i t}\right)$ ) and the actual share return $\left(R_{i t}\right)$ for each share. The expected share return $\left(\hat{R}_{i t}\right)$ during the event period is calculated using the estimated modified market model.

\section{Formula 1: $\quad$ Modified market model}

$$
\begin{aligned}
& R_{i t}=\alpha_{i}+\beta_{i} R_{m t}+u_{i t} \\
& u_{i t}=\sigma_{i t} e_{i t} \\
& \sigma_{i t}^{2}=\theta_{i 0}+\theta_{i 1} u_{i t-1}^{2}+\emptyset_{i} \sigma_{i t-1}^{2}
\end{aligned}
$$

$$
\begin{array}{ll}
\text { where } & \begin{array}{ll}
R_{i t} & \text { is the return for share } \mathbf{i} \text { on day } \mathbf{t} \\
R_{m t} & \text { is the return for the all-share index on day } \mathbf{t} \\
u_{i t} & \text { is the residual or non market return for share } \mathbf{i} \text { on day } \mathbf{t} \\
\alpha_{i} \text { and, } \beta_{i}, & \\
\theta_{i 0}, \theta_{i 1} \text { and } \varphi_{i} & \text { are parameters to be estimated } \\
\sigma_{i t}^{2} & \text { is the conditional variance }
\end{array}
\end{array}
$$

\section{Formula 2: $\quad$ Abnormal returns (AR)}

$$
\hat{R}_{i t}-R_{i t}=A R \quad\{\mathrm{t}=\text { day }-20 \text {, day } 0 \text { and day }+20\}
$$

$$
\begin{array}{lll}
\text { where } & \hat{R}_{i t} & \text { is the expected return on share } \mathbf{i} \text { in period } \mathbf{t} \\
& R_{i t} & \text { is the actual return on the share } \mathbf{i} \text { in period } \mathbf{t} \\
A R & \text { is the abnormal return }
\end{array}
$$

With the share return affected by both the SENS announcement and other firm-specific effects, the abnormal return estimator is likely to result in a larger variance during the event period than in non-event periods and hence event-induced heteroscedasticity is likely (Beaver, 1968). In accounting for heteroscedasticity, Collins and Dent (1984) propose using a least squares technique, while Boehmer, Masumeci and Poulsen (1991) propose standardising the abnormal return estimates by their estimated standard deviation. Corhay and Tourani-Rad (1996) used the generalised autoregressive conditional heteroscedasticity (GARCH) model for the variance of the error term in the return equation.

The approach followed in the current study is to standardise the abnormal returns by an estimate of the conditional variance where the conditional variance is estimated using another GARCH model, which this time includes the event period returns. A dummy variable taking a value of 1 during the event period and a value of 0 otherwise is also added to the GARCH structure to estimate slow as well as abrupt changes in the conditional variance during the event period.

Scaling the abnormal returns with the conditional variance estimated in this way controls for event-induced heteroscedasticity as well as variances between different companies' abnormal returns (Bremer \& Zhang, 2007). 
Formula 3: Standardised abnormal returns (SAR)

$$
S A R_{i t}=\frac{A R_{i t}}{\sigma_{i t}^{2}}
$$

$\begin{array}{ll}\text { where } & S A R_{i t} \\ & A R_{i t} \\ & \sigma_{i t}^{2}\end{array}$

is the standardised abnormal return is the abnormal return on the share $\mathbf{i}$ in period $\mathbf{t}$ is the conditional variance estimated using a second GARCH model

The standardised abnormal returns are then averaged per day to produce the average standardised abnormal returns (ASAR). In addition to being average per day, the SAR are accumulated for each day, day -20 until day -19 , day -20 until day -18 , day -20 until day -17 , etc. to produce the average cumulative standardised abnormal return. The ASARs and ACSARs were then tested for significance using the standard T-test.

A further consideration is the potential impact of thinly traded shares. Examining both the daily trading volume data for exchange traded and stocks, Cowan and Sergeant (1996) find that while the use of daily returns to isolate share price reactions to an event is important, thinly traded shares may impact on the results found. Cowan (1992) finds that as thinly traded stocks are more likely to be characterised by numerous zero and large non-zero returns, they are more likely to result in non-normal return distributions, which, in turn, distort the variance estimates required for the standardised abnormal return test. While Corrado (1989) uses a nonparametric rank test and thus avoids the dependence on normality of return distributions, Boehmer et al. (1991) developed a standardised cross-sectional test to address this issue. The current study has adopted a simpler approach by excluding companies that have no shares traded for more than $50 \%$ of the days in the window period. This resulted in the exclusion of four of the original 38 companies identified in TABLE 1.

In addressing the efficiency of the JSE, the ACSARs are plotted to graphically illustrate the efficiency of the market. Where the financial restatement announcement has no effect, the abnormal return is expected to be zero. Any movements away from zero are, therefore, attributed to the restatement announcement. It is, however, important to remember that while ACSARs around the zero are expected and that the ACSARs are expected to deviate further away from zero if the SENS announcement contains any information value. The plotted ACSARs can, therefore, be used to graphically illustrate the test of JSE efficiency and the informational value of the SENS announcement.

\subsection{Sample}

TABLE 1 presents the chronological distribution of the 38 companies identified as making SENS announcements of financial restatement resulting from investigations by or work of the GMP for the period from 1 September 2002 - 30 September 2010. With the exception of 2004, the annual number of financial restatements resulting from work of the GMP included in the sample did not exceed four.

In 2004, 21 restatements occurred. Fifteen of these GMP financial restatements during 2004 resulted from a recommendation by the GMP to the JSE Listings Division that share incentive scheme trusts be consolidated into the group financial statements. Companies subsequently issuing a SENS announcement to this effect were also included in the sample. There were no GMP financial restatement SENS announcements during 2009. 
TABLE 1: Chronological distribution of financial restatement

\begin{tabular}{|c|c|c|c|}
\hline $\begin{array}{l}\text { JSE } \\
\text { Ticker }\end{array}$ & Company & SENS Date & $\begin{array}{l}\text { Share Traded } \\
\text { (in millions) }\end{array}$ \\
\hline ART & ARGENT INDUSTRIAL LIMITED & $22-0 c t-2002$ & 16.48 \\
\hline TNT & TONGAAT-HULETT GROUP LIMITED & $22-N o v-2002$ & 52.05 \\
\hline SNT & SANTAM LIMITED & $17-$ Mar-2003 & 22.32 \\
\hline MTO & MATHOMO GROUP LIMITED & 25-Mar-2003 & 64.68 \\
\hline PNC & PINNACLE TECHNOLOGY HOLDINGS LIMITED & 27-Mar-2003 & 556.90 \\
\hline $\mathrm{CDZ}$ & CADIZ HOLDINGS LIMITED & $30-J u l-2003$ & 356.63 \\
\hline WHL & WOOLWORTHS HOLDINGS LIMITED & $12-F e b-2004$ & 14.19 \\
\hline MSM & MASSMART HOLDINGS LIMITED & $26-F e b-2004$ & 114.45 \\
\hline DTA & DELTA EMD LIMITED & $01-M a r-2004$ & 52.99 \\
\hline $\mathrm{ADH}$ & ADVTECH LIMITED & 23-Mar-2004 & 189.82 \\
\hline BDS & BRIDGESTONE FIRESTONE MAXIPREST LIMITED & $31-$ Mar-2004 & 210.93 \\
\hline AMA & AMALGAMATED APPLIANCE HOLDINGS LIMITED & 21-Apr-2004 & 106.60 \\
\hline JDG & JD GROUP LIMITED & 18-May-2004 & 114.22 \\
\hline PGR & PEREGRINE HOLDINGS LIMITED & 20-May-2004 & 41.38 \\
\hline MPC & MR PRICE GROUP LIMITED & 26-May-2004 & 16.48 \\
\hline IMR & IMR INVESTMENTS LIMITED & 31-May-2004 & 29.06 \\
\hline ART & ARGENT INDUSTRIAL LIMITED & 03-Jun-2004 & 40.29 \\
\hline SCN & SCHARRIG MINING LIMITED & 03-Jun-2004 & 60.40 \\
\hline $\mathrm{CSH}$ & CS COMPUTER SERVICES HOLDINGS LIMITED & 14-Jul-2004 & 10.27 \\
\hline CSB & CASHBUILD LIMITED & 21-Jul-2004 & 12.80 \\
\hline UTR & UNITRANS LIMITED & 24-Aug-2004 & 300.98 \\
\hline MUR & MURRAY \& ROBERTS HOLDINGS LIMITED & 26-Aug-2004 & 129.81 \\
\hline PAP & PANGBOURNE PROPERTIES LIMITED & 26-Aug-2004 & 396.25 \\
\hline MET & METROPOLITAN HOLDINGS LIMITED & $08-\operatorname{Sep}-2004$ & 1.27 \\
\hline NWL & NU-WORLD HOLDINGS LIMITED & $26-0 c t-2004$ & 12.30 \\
\hline IDI & IDION TECHNOLOGY HOLDINGS LIMITED & $14-D e c-2004$ & 51.15 \\
\hline DEC & DECILLION LIMITED & $15-D e c-2004$ & 36.71 \\
\hline$\varepsilon L X$ & દLEXIR TECHNOLOGY HOLDINGS LIMITED & $14-A p r-2005$ & 290.74 \\
\hline AST & AST GROUP LIMITED & $06-J u l-2005$ & 28.78 \\
\hline LAB & LABAT AFRICA LIMITED & 31-Aug-2005 & $1,140.67$ \\
\hline NTC & NETWORK HEALTHCARE HOLDINGS LIMITED & $11-N o v-2005$ & 233.61 \\
\hline AFR & AFGRI LIMITED & $08-N o v-2006$ & 22.50 \\
\hline yBA & YOMHLABA RESOURCES LIMITED & 27-Jun-2007 & 96.25 \\
\hline BFS & BLUE FINANCIAL SERVICES LIMITED & 16-Aug-2007 & 16.64 \\
\hline$A \varepsilon R$ & AMALGAMATED ELECTRONIC CORPORATION LIMITED & $26-N o v-2007$ & 128.80 \\
\hline
\end{tabular}




\begin{tabular}{llcc}
\hline $\begin{array}{l}\text { JSE } \\
\text { Ticker }\end{array}$ & \multicolumn{1}{c}{ Company } & SENS Date & $\begin{array}{c}\text { Share Traded } \\
\text { (in millions) }\end{array}$ \\
\hline ATR & AFRICA CELLULAR TOWERS LIMITED & 27 -May-2008 & 54.73 \\
\hline BEE & BEGET HOLDINGS LIMITED & 04-Jun-2010 & 43.77 \\
\hline CMO & CHROMETCO LIMITED & 27-Aug-2010 & 9.50 \\
\hline
\end{tabular}

Source: Author's results using McGregor BFA.

* For the sake of brevity, the JSE ticker is subsequently used for all future references to a company.

During the estimation period, the average number of days without shares being traded was 19.97 days out of the potential 159 days, representing some $12.6 \%$ of the estimation period. Within the event period, the average number of days across all companies without shares being traded was 5 days representing $12.5 \%$ of the potential trading days in the estimation period. The frequency of non-trading days during the estimation and event periods is accordingly considered acceptable.

\section{RESULTS}

The results for the standardised abnormal returns across all companies during the event period are presented first. This is followed by the average cumulative standardised abnormal returns and a graphical illustration thereof.

\subsection{Standardised abnormal returns}

The estimation period data is used to estimate the modified market model. Abnormal returns are then obtained for each company during the event period by subtracting predicted (expected) values from the actual return values. These abnormal returns are standardised by a conditional variance estimated using a second GARCH model with a dummy variable for the event period. TABLE 2 provides the cross-sectional (or across company) averages of the standardised abnormal return (ASAR) for every day in the event period with tests of the values significantly different from 0 .

TABLE 2: Daily Average Standardise Abnormal Return for the event period

\begin{tabular}{cccccc}
\hline Day & $n$ & Average SAR & Std Dev & t Value & Pr $>/ t /$ \\
\hline-20 & 34 & -0.056 & 0.423 & -0.770 & 0.446 \\
\hline-19 & 34 & 0.092 & 0.412 & 1.300 & 0.204 \\
\hline-18 & 34 & 0.001 & 0.395 & 0.010 & 0.990 \\
\hline-17 & 34 & -0.045 & 0.383 & -0.680 & 0.500 \\
\hline-16 & 34 & -0.013 & 0.408 & -0.180 & 0.857 \\
\hline-15 & 34 & -0.042 & 0.570 & -0.430 & 0.673 \\
\hline-14 & 34 & 0.009 & 0.505 & 0.110 & 0.917 \\
\hline-13 & 34 & -0.061 & 0.321 & -1.110 & 0.274 \\
\hline-12 & 34 & -0.035 & 0.598 & -0.340 & 0.732 \\
\hline
\end{tabular}




\begin{tabular}{|c|c|c|c|c|c|c|}
\hline Day & $n$ & Average SAR & Std Dev & t Value & $\operatorname{Pr}>|t|$ & \\
\hline-11 & 34 & 0.075 & 0.388 & 1.120 & 0.271 & \\
\hline-10 & 34 & -0.154 & 0.481 & -1.870 & 0.071 & * \\
\hline-9 & 34 & 0.085 & 0.420 & 1.180 & 0.247 & \\
\hline-8 & 34 & -0.064 & 0.293 & -1.270 & 0.213 & \\
\hline-7 & 34 & 0.016 & 0.476 & 0.200 & 0.842 & \\
\hline-6 & 34 & 0.042 & 0.361 & 0.690 & 0.498 & \\
\hline-5 & 34 & -0.078 & 0.315 & -1.440 & 0.158 & \\
\hline-4 & 34 & -0.055 & 0.463 & -0.690 & 0.493 & \\
\hline-3 & 34 & -0.052 & 0.387 & -0.780 & 0.438 & \\
\hline-2 & 34 & 0.102 & 0.444 & 1.340 & 0.189 & \\
\hline-1 & 34 & 0.049 & 0.414 & 0.680 & 0.499 & \\
\hline Day 0 & 34 & -0.028 & 0.729 & -0.220 & 0.824 & \\
\hline 1 & 34 & -0.068 & 0.541 & -0.740 & 0.467 & \\
\hline 2 & 34 & 0.023 & 0.327 & 0.420 & 0.679 & \\
\hline 3 & 34 & 0.002 & 0.402 & 0.040 & 0.972 & \\
\hline 4 & 34 & 0.123 & 0.702 & 1.020 & 0.315 & \\
\hline 5 & 34 & -0.212 & 0.531 & -2.330 & 0.026 & $\star \star$ \\
\hline 6 & 34 & 0.027 & 0.329 & 0.480 & 0.635 & \\
\hline 7 & 34 & -0.107 & 0.525 & -1.180 & 0.245 & \\
\hline 8 & 34 & 0.020 & 0.463 & 0.250 & 0.807 & \\
\hline 9 & 34 & 0.122 & 0.371 & 1.920 & 0.064 & * \\
\hline 10 & 34 & 0.064 & 0.565 & 0.660 & 0.512 & \\
\hline 11 & 34 & -0.071 & 0.290 & -1.420 & 0.166 & \\
\hline 12 & 34 & 0.002 & 0.389 & 0.020 & 0.982 & \\
\hline 13 & 34 & 0.048 & 0.333 & 0.840 & 0.407 & \\
\hline 14 & 34 & -0.119 & 0.416 & -1.680 & 0.103 & \\
\hline 15 & 34 & 0.083 & 0.516 & 0.940 & 0.354 & \\
\hline 16 & 34 & 0.020 & 0.362 & 0.320 & 0.749 & \\
\hline 17 & 34 & 0.095 & 0.587 & 0.940 & 0.352 & \\
\hline 18 & 34 & 0.088 & 0.485 & 1.060 & 0.296 & \\
\hline 19 & 34 & -0.108 & 0.372 & -1.690 & 0.101 & \\
\hline 20 & 34 & -0.041 & 0.297 & -0.800 & 0.431 & \\
\hline
\end{tabular}

Source: Authors'calculations

*, ** Significant at the 0.1 and 0.05 level respectively 
The ASARs fluctuate around 0 , with approximately $50 \%$ of the ASARs negative and $50 \%$ positive. This in itself is an interesting finding as it is unlikely that a restatement announcement would represent good news with management effectively acknowledging that they previously provided erroneous or fraudulent results. If an event is anticipated the ASAR returns days leading to the announcement date should reflect this. A negative ASAR is found for 11 of the 20 days leading up to the announcement date. A plausible explanation is that news of financial restatement may have leaked to the market before the official SENS announcement thus resulting in negative ASARs.

Interpreting the results around the announcement date is difficult in that, although significant ASARs were found at days $-10,+5$ and +9 , no significant ASARs were found in any sequential days. The significant negative abnormal return of day -10 may possibly be the result of insider trading and is recommended for future research. Although not significant, a negative ASAR is found for days 0 and day 1 . Although not significant, a positive abnormal return was found for days $+2,+3,+4$. After a slight delay subsequent to the announcement date (day 0 ), a statistically significant negative ASAR was found at day +5 . The results show that financial restatement announcements contain value relevant information for the shareholders but that the market is slow to react to such an announcement. It is accordingly deduced that the market imbibes this release of information so slowly that it is possible for investors to earn abnormal returns during such an announcement period.

\subsection{Cumulative standardised abnormal returns}

In order to provide a clearer picture of the effect these restatements had on share price returns and graphically illustrate the market efficiency, the cumulative standardised abnormal returns (CSAR) are calculated for each company for each day during the event period. The CSARs are averaged across companies to get the average cumulative standardised abnormal returns (ACSAR) that are tested for significance using a T-test. FIGURE 2 presents these results.

FIGURE 2 illustrates that, although no significant ACSAR were found, the financial restatement announcement had a negative impact on the share price with ACSAR over the majority of the event period being negative. Corresponding with the significant negative ASARs found at days 10 and day +5 of TABLE 2, FIGURE 2 shows a sharp decrease in the ACSAR for the same periods. Similarly, where a significant positive ASAR is found for day +9 , a sharp increase can be seen for the corresponding day in FIGURE 2. The graph shows that financial restatement announcements contain value relevant information for the shareholders and that the market slowly imbibes this new information, with the CSAR taking approximately ten days to return to the CSAR of day 0 .

\section{SUMMARY AND CONCLUSION}

The research objectives of this study is to test, in semi-strong form, the efficiency of the JSE in reacting to the SENS announcements of financial restatement resulting from investigations by or work of the GMP and to examine share price reaction to such SENS announcements. After identifying 38 companies making SENS announcements of such financial restatements, four of the 38 companies' shares were thinly traded and thus excluded from the sample. A two-stage event test that scales abnormal returns with conditional variance, estimated with a GARCH $(1,1)$ component and an event indicator, was used to examine the effect of the financial restatement announcements on the share prices. 


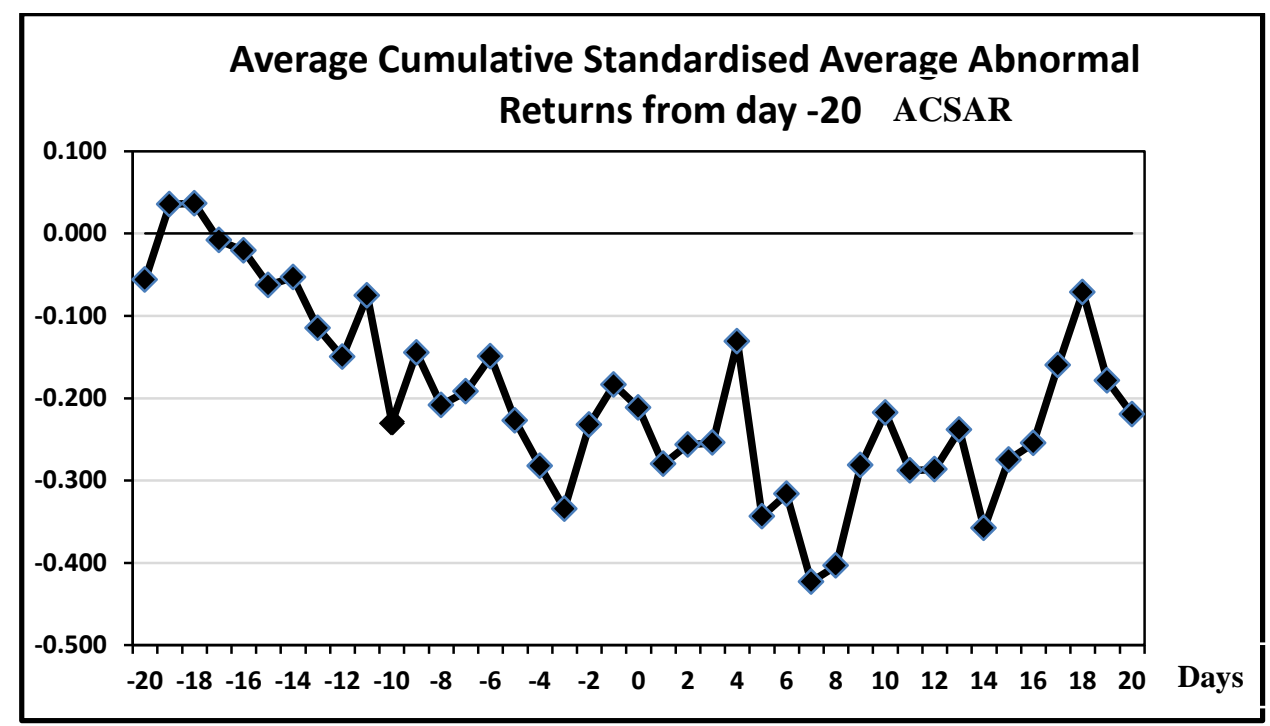

FIGURE 2: ASCAR from day -20

\section{Source: Authors'results}

The results of the two-stage event test show that more than half of the 20 days leading up to the announcement date reflect a negative ASAR. While it is acknowledged that only day - 10 was significant at the $5 \%$ level, it would appear that the event may have been partially anticipated by the market. During the period subsequent to the announcement, positive abnormal returns are found on days $+2,+3,+4$ with a significant negative ASAR being found at day +5 . Significant at the $1 \%$ level, the negative ASAR found at day +5 indicates that the announcement does convey new information to the market and that information has a significant negative impact on the share return. Supporting these findings, negative CSARs were also found on days -10 and +5 , which correspond with the significant negative ASARs. It is further noted that the CSARs were found to be negative over the majority of the event period indicating an overall negative market reaction to the announcement. The conclusion is thus reached that announcements of financial restatements, resulting from investigations by or work of the GMP, contain value relevant information for the shareholders.

In drawing a conclusion as to the semi-strong form efficiency of the JSE, cognisance is taken of how quickly the market impounds announcements and/or events into the share prices of listed companies. Given that the market takes five days from the announcement date to react to financial restatement announcements, evidenced by the significant negative ASAR found on day +5 , the JSE is accordingly not found to be efficient in semi-strong form.

It should, however, be noted while this study finds the JSE not to be efficient in semi-strong form, Thompson and Ward (1995), performing an extensive review of studies examining the efficiency of the JSE, conclude that no conclusive answer as to the efficiency of the JSE could be reached. Further research on the efficiency of the JSE in semi-strong from is recommended.

The secondary research objective was to examine share price reaction to SENS announcements of financial restatement resulting from investigations or technical recommendations by the GMP. With negative CSARs being found for 39 of the 41 day event period, it is concluded that share 
prices react negatively to financial restatement announcements resulting from the work of the GMP.

\section{LIMITATIONS AND RECOMMENDATIONS FOR FUTURE RESEARCH}

While it is acknowledged that prior studies have found that the market reaction to restatements are influenced by factors such as the role of corporate governance (Agrawal \& Chadha, 2005), the role of management (Desai et al., 2006; Karpoff, Scott Lee \& Martin, 2008), management turnover and fraud (Land, 2010), litigation risk (Palmrose \& Scholz, 2004), the role of the auditor (Chin \& Chi, 2009), the role that earnings management plays (Ettredge, Scholz, Smith \& Lili, 2010) and various other aspects (Palmrose et al., 2004), and that these factors have an impact on the market reaction to financial restatement, these aspects fall beyond the scope of this study.

It is further acknowledged that only including financial restatements resulting from investigations by or work of the GMP reduces the sample size, and using a larger sample including all types of financial restatement may, firstly, result in more robust results and, secondly, provide the opportunity to examine aspects such as the type of financial restatement as in those mentioned above.

Although supporting the findings of Glass and Smit (1995) and Knight and Affleck-Graves (1983), the finding that the JSE is not efficient in semi-strong form contradicts the findings of Kana (1986), Atkins (1995) and Okeahalam and Jefferis (1999). Further research examining the efficiency of the JSE in semi-strong form is thus recommended.

\section{LIST OF REFERENCES}

Agrawal, A. \& Chadha, S. (2005). Corporate Governance and Accounting Scandals. Journal of Law \& Economics, 48(2), pp. 371-406.

Atkins, M.D. (1995). The Supply and Demand Effect of Block Transactions on Share Prices. Unpublished Dissertation. Johannesburg: University of the Witwatersrand.

Ball, R. \& Brown, P. (1968). An Empirical Evaluation of Accounting Income Numbers. Journal of Accounting Research, 6(2), pp. 159-178.

Beaver, W.H. (1968). The Information Content of Annual Earnings Announcements. Journal of Accounting Research, 6(3), pp. 67-92.

Binder, J.J. (1998). The Event Study Methodology since 1969. Review of Quantitative Finance and Accounting, 11 (2), pp. 111-137.

Boehmer, E., Masumeci, J. \& Poulsen, A.B. (1991). Event-Study Methodology under Conditions of Event-Induced Variance. Journal of Financial Economics, 30(2), pp. 253-272.

Bremer, R. \& Zhang, Z. (2007). Extensions of the Standardized Cross-Sectional Approach to ShortHorizon Event Studies. Journal of Financial Research, 30(4), pp. 495-513.

Brown, S.J. \& Warner, J.B. (1980). Measuring Security Price Performance. Journal of Financial Economics, 8(3), pp. 205-258. 
Browning, E.S. \& Weil, J. (2002). Stocks Take a Beating as Accounting Worries Spread Beyond Enron. Wall Street Journal - Eastern Edition, 239(21), pp. Al.

Chin, C.L. \& Chi, H.Y. (2009). Reducing Restatements with Increased Industry Expertise. Contemporary Accounting Research, 26(3), pp. 729-765.

Collins, D.W. \& Dent, W.T. (1984). A Comparison of Alternative Testing Methodologies Used in Capital Market Research. Journal of Accounting Research, 22(1), pp. 48-84.

Corhay, A. \& Tourani-Rad, A. (1996). Conditional Heteroskedasticity Adjusted Market Model and an Event Study. The Quarterly Review of Economics and Finance, 36(4), pp. 529-538.

Corrado, C.J. (1989). A Nonparametric Test for Abnormal Security-Price Performance in Event Studies. Journal of Financial Economics, 23(2), pp. 385-395.

Cowan, A.R. (1992). Nonparametric Event Study Tests. Review of Quantitative Finance and Accounting, 2, pp. 343-358.

Cowan, A.R. \& Sergeant, A.M.A. (1996). Trading Frequency and Event Study Test Specification. Journal of Banking and Finance, 20(10), pp. 1731-1757.

Dechow, P.M., Sloan, R.G. \& Sweeney, A.P. (1996). Causes and Consequences of Earnings Manipulation: An Analysis of Firms Subject to Enforcement Actions by the Sec. Contemporary Accounting Research, 13(1), pp. 1-36.

Deegan, C. (2007). Financial Accounting Theory, $2^{\text {nd }}$ edition. New South Wales: McGraw-Hill Australia Pty Limited.

Desai, H., Hogan, C.E. \& Wilkins, M.S. (2006). The Reputational Penalty for Aggressive Accounting: Earnings Restatements and Management Turnover. Accounting Review, 81(1), pp. 83-112.

Ettredge, M., Scholz, S., Smith, K.R. \& Lili, S. (2010). How Do Restatements Begin? Evidence of Earnings Management Preceding Restated Financial Reports. Journal of Business Finance \& Accounting, 37(3/4), pp. 332-355.

Fama, દ.F. (1970). Efficient Capital Markets: A Review of Theory and Empirical Work. Journal of Finance, 25(2), pp. 383-417.

Fama, E.F., Fisher, L., Jensen, M.C. \& Roll, R. (1969). The Adjustment of Stock Prices to New Information. International Economic Review, 10(1), pp. 1-21.

Gertsen, F.H.M., van Riel, C.B.M. \& Berens, G. (2006). Avoiding Reputation Damage in Financial Restatements. Long Range Planning, 39(4), pp. 429-456.

Glass, R.D. \& Smit, E.V. (1995). The Relationship between Changes in Money Supply and Changes in Share Prices: The Semi-Strong Form Efficiency of the Johannesburg Stock Exchange Revisited. South African Journal of Business Management, 26(1), pp. 131-140.

Gleason, C.A., Jenkins, N.T. \& Johnson, W.B. (2008). The Contagion Effects of Accounting Restatements. Accounting Review, 83(1), pp. 83-110.

Hellman, M.D. (2002). Lead-Lag Indicators on the Johannesburg Stock Exchange: An Efficiency Test. Unpublished Dissertation. Johannesburg: University of the Witwatersrand.

International Accounting Standards Board. (2010). A Guide through International Financial Reporting Standards (Vol. 1B). London: International Accounting Standards Committee Foundation.

Jefferis, K. \& Smith, G. (2004). Capitalisation and Weak-Form Efficiency in the JSE Securities Exchange. South African Journal of Economics, 72(4), pp. 684-707. 
Jefferis, K. \& Smith, G. (2005). The Changing Efficiency of African Stock Markets. South African Journal of Economics, 73(1), pp. 54-67.

JSE Limited. (2010a). Equity Market Statistics [Online] Available:http://www.jse.co.za/Documentsand-Statistics/Marketstatistics/Equity-Market-Statistics.aspx. (Accessed 3 November 2010)

JSE Limited. (2010b). History of the JSE. [Online] Available: http://www.jse.co.za/About-Us/HistoryOf-The-JSE.aspx (Accessed 14 October 2010).

JSE Limited. (2010c). JSE Limited Listings Requirements (Service Issue 13). [Online] Available: http://www.jse.co.za/How-To-List-A-Company/Main-Board/Listing-requirements/JSE-listingrequirements.aspx. (Accessed 16 August 2010)

JSE Limited. (2010d). Wef Competiveness Report 2010-2011. [Online] Available: http://www.jse.co.za/About-Us/Media/Press-Releases/Full-Story/10-09-

14/WEF_Competiveness_Report_20102011_South_Africa_boasts_best_regulation_of_securities_exchanges.aspx. (Accessed 9 November 2010)

JSE Limited. (2011). JSE/ SAICA Media Release: Pro Active Monitoring of Financial Results. [Online] Available:

http://www.saica.co.za/Portals/0/documents/SSE\%20SAICA\%20PRESS\%20RELEASE\%20_2_\%20_2_\% 20_2_.pdf. (Accessed 23 May 2012)

Kana, S.P. (1986). The Efficiency of the Johannesburg Stock Exchange with Respect to Takeover Information. Unpublished Dissertation. Johannesburg: University of the Witwatersrand.

Karpoff, J.M., Scott Lee, D. \& Martin, G.S. (2008). The Consequences to Managers for Financial Misrepresentation. Journal of Financial Economics, 88(2), pp. 193-215.

Knight, R.F. \& Affleck-Graves, J.F. (1983). The Efficient Market Hypothesis and a Change to Lifo: An Empirical Study on the JSE. Investment Analysts Journal, 21, pp. 21-33.

Kothari, S.P. (2001). Capital Markets Research in Accounting. Journal of Accounting and Economics, 31(1-3), pp. 105-231.

Land, J.K. (2010). Ceo Turnover around Earnings Restatements and Fraud. Pacific Accounting Review (Emerald Group Publishing Limited), 22(3), pp. 180-198.

Mabhunu, M. (2004). The Market Efficiency Hypothesis and the Behaviour of Stock Returns on the Johannesburg Securities Exchange. Unpublished Dissertation. Grahamstown: Rhodes University.

MacDonald, A.S. (1995). The Impact of the Finance Week 200 Publication on Share Prices. Unpublished Dissertation. Johannesburg: University of the Witwatersrand.

Magnusson, M.A. \& Wydick, B. (2002). How Efficient Are Africa's Emerging Stock Markets? Journal of Development Studies, 38(4), pp. 141-156.

Mandal, N. \& Rao, N.K. (2010). Semi-Strong Form of Indian Stock Market Efficiency: An Empirical Study. Vilakshan: The XIMB Journal of Management, 7(1), pp. 1-16.

Marciukaityte, D., Szewczyk, S.H. \& Varma, R. (2009). Voluntary Vs. Forced Financial Restatements: The Role of Board Independence. Financial Analysts Journal, 65(5), pp. 1-15.

McGregor BFA. (2010). Company Profile. [Online] Available:

http://www.mcgregorbfa.com/CompanyProfile.aspx. (Accessed 17 November 2010) 
Okeahalam, C.C. \& Jefferis, K.R. (1999). An Event Study of the Botswana, Zimbabwe and Johannesburg Stock Exchange. South African Journal of Business Management, 30(4), pp. 131-141.

Palmrose, Z.-V., Richardson, V.J. \& Scholz, S. (2004). Determinants of Market Reactions to Restatement Announcements. Journal of Accounting and Economics, 37 (1), pp. 59-89.

Palmrose, Z.-V. \& Scholz, S. (2004). The Circumstances and Legal Consequences of Non-GAAP Reporting: Evidence from Restatements. Contemporary Accounting Research, 21(1), pp. 139-180.

Philpott, M.F. \& Firer, C. (1995). Share Price Anomalies and the Efficiency of the JSE. Investment Analyst Journal, 40, pp. 39-4l.

Qi, C., Goldstein, I. \& Wei, J. (2007). Price Informativeness and Investment Sensitivity to Stock Price. Review of Financial Studies, 20 (3), pp. 619-650.

Rezaee, Z. (2004). Corporate Governance Role in Financial Reporting. Research in Accounting Regulation, 17, pp. 107-149.

Robertson, A. C., Page, M. \& Smit, E. v. d. M. (1999). Share Market Reaction to Large Daily Price Declines: Evidence from the JSE. Journal for Studies in Economics and Econometrics, 23(3), pp. 15-48.

Smith, G. (2008). Liquidity and the Informational Efficiency of African Stock Markets. South African Journal of Economics, 76(2), pp. 161-175.

Smith, G., Jefferis, K. \& Ryoo, H.J. (2002). African Stock Markets: Multiple Variance Ratio Tests of Random Walks. Applied Financial Economics, 12(7), pp. 475-484

Thompson, A.R. \& Ward, M.J.D. (1995). The Johannesburg Stock Exchange as an Efficient Market: A Review. Journal for Studies in Economics and Econometrics, 19, pp. 33-63.

$\mathrm{Xu}, \mathrm{T}$., Jin, J.J. \& Li, D. (2009). Long-Term Market Reactions to Earnings Restatements. Academy of Accounting \& Financial Studies Journal, 13(3), pp. 45-65. 